\title{
PRODUCTION PARAMETERS AND SOME CHARACTERISTICS OF KÖKEZ STRAINED YOGURT
}

\author{
Seval Sevgi KİRDAR ${ }^{1}$, Kubra NARMAN ${ }^{2}$ \\ ${ }^{1}$ Mehmet Akif Ersoy University, Burdur Food Agriculture and Livestock Vocational School, Department of Food \\ Processing, Milkand Dairy Products Program, İstiklal Campus, 15130 Burdur, Turkey \\ ${ }^{2}$ Mehmet Akif Ersoy University, Burdur Education Faculty İstiklal Campus, 15130 Burdur, Turkey \\ DOI: https://doi.org/10.51193/IJAER.2021.7313
}

\begin{abstract}
Strained yogurt (sometimes known by other names, such as torba, kese, süzme, filtered or concentrated yogurt) is a concentrated fermented product in the Anatolia region for centuries. In general, the strained yogurt is manufactured by separating the whey in the stirred yogurt until it reaches a total solid level of 22-28\%. Burdur Kökezyogurt is one of themost popular strained yogurts in the Burdur province of Turkey. It's high solids contents and long self-life. The mos timportant feature of Kökezyogurt is its taste and texture. The product has a cream/white color, a soft and smooth body, and is highly spreadable with little syneresis, and the primary flavors are defined as sweet, sour, and astringent. The $\mathrm{pH}$ values of Kökezyogurt vary between 3.63 and 3.79 , titratable acidity at $1.52-2.08 \%$ LA, dry matter at $21.25-27.35 \%$, protein content at 9.18$11.92 \%$, and fat content at $7.80-8.40 \%$.
\end{abstract}

Keywords: Traditional fermented milk products, Concentrated yogurt, Strained yogurt, characteristic of Kökez strained yogurt, Turkey

\section{INTRODUCTION}

Fermented milk originates from the Near East and subsequently became popular in Eastern and Central Europe. The first example of fermented milk, including yoghurt, was presumably produced accidentally by nomads [1]. There are more than 400 yoghurt and fermented milk products that are similar to yoghurt, which are known under different names throughout the world [2]. Fermented milks classification could be done based on the fermentation type they undergo, such as lactic, yeast-lactic, and mould-lactic. Products produced by lactic fermentation could be classified depending on the features of LAB, such as mesophilic, thermophilic, and therapeutic (probiotic) [3, 4]. Yogurt is included in these classifications as a thermophilic lactic- 
International Journal of Agriculture and Environmental Research

ISSN: 2455-6939

Volume: 07, Issue: 03 "May-June 2021"

acid fermentation product [2,5,6] (Tamime and Crawford1984; Kurman et al., 1992, Keser, 2018).

Yogurt is an ancient fermented milk product date to more than $10000 \mathrm{y}$ ago as the way of life of humans changed from food gathering to food-producing [2]. The etymology of the yoghurt name comes from the Turkish yoğurt and is associated with yoğurmak and yoğun, which mean "to knead" and "dense" or "thick", respectively. The use of yogurt by mediaeval Turks is recorded in Diwan Lughat al-Turk by Mahmud Kashgari and Kutadgu Bilig by Yusuf Has Hajib written in A.D. 1070. In both texts, the word "yogurt" is mentioned in different sections and its use by nomadic Turks is described. These two books are the earliest recorded information about this fermented milk product [7](Yildiz, 2010).

Fermented milks are manufactured throughout the world, and approximately 400 generic names are applied to traditional and industrialized products [6] (Kurmann et al, 1992). As an indispensable flavor in traditional Turkish and Anatolian nutritional cultures, strained yogurt is one of the oldest and most important items [8](Yaygin 1999). The main principle for producing strained yogurt is to reduce the water content by removing the serum phase to increase product resistance to deterioration [9] (Kurdar and Gün, 2002). In general, the concentrated yoghurt is manufactured by separating the whey in the stirred yoghurt until it reaches a total solid level of $23-28 \%$. This product is known as "Torba" or "Suzme" yoghurt and Kurut (dried yoğurt) in Turkey. In the Middle East, strained yoghurt is popularly known as "labneh," and various labneh-related products are manufactured in other countries, such as "Greek style" (Europe), "Chakka" and "Shirkland" (in India), "Skyr" (İreland), "Ymer" (Denmark), "Tan or Than" (Armenia), and "Mastou" (Iraq) [9, 10, 11,12].

Several types of concentrated yogurt have traditionally been produced Kurut, Torba (strained) yogurt, Tulum yogurt, Peskuten, Salted yogurt, and Winter yogurt in Turkey [2, 9, 13]. Strained yoghurt (sometimes known by other names, such as torba, kese, süzme, filtered or concentrated yoghurt) is a concentrated fermented product in the Anatolia region for centuries [14]. It has been defined as a semisolid product derived from yoghurt by removing part of its water and water-soluble components, mainly lactose and salts, using a cloth bag. It has better taste and texture than set yogurt and widely consumed in Turkey [9].

In the Mediterranean and southern regions of Turkey, salted or winter yoghurt is traditionally made by boiling and then salting the yoghurt to prolong its quality. Salting is an age-old method by which to preserve food, but the incorporation of salt into concentrated yoghurt also acts as a neutralizing agent to reduce its acidity. To reduce cooking time, the yoghurt whey is removed using a cloth bag until $\leq 17-18 \%$ total solids remain. When the cooking stage is complete, the salted yoghurt is transferred into another container to cool $[9,12,14]$. 
Winter yoghurt is one of the most popular varieties of traditional dairy products manufactured in Van. This yoghurt is known as yoghurt cheese or salted yoghurt in the Mediterranean and some regions of Turkey because of its high dry-matter content and long shelf life. In addition, strained and winter yoghurts have not been manufactured in industrial plants. In most regions of Turkey, sheep milk is combined with cow milk to produce winter yoghurt, which is one of the most wellliked traditional dairy products [15].

Silivri yogurt has been produced in the Trakya region since the 1870s. Of the various traditional yogurts, winter yogurt is found in the Mediterranean region (Hatay) and Kurut is consumed with soup, ravioli, and some regional foods in Central Anatolia (Sivas) and Eastern Anatolia (Bingöl). Denizli'syanık yogurt is found in Denizli, Tulum in Antalya, Dorakin Kayseri, Kökez in Burdur and Niğde, and Külek in Isparta and Trabzon [2].

Kökez yoghurt is a fermented milk product whose protein content is adjusted to at least $6 \%$ by mass as a result of removing the serum from the yoghurt with an appropriate technology or method, and containing live and active starter bacteria at the expiry date by adding the yogurt culture. The most important feature of Kökez yoghurt is its taste and texture.

The number of studies on strained yoghurt has also increased daily. Some studies have determined the physical, chemical, and microbiological features of yogurt (Tablo 1) Other studies have concentrated on production technology $[35,36]$. No research has been found on the production parameters of Burdur Kökez yogurt and its properties.

The aim of this study was to determine the traditional production method and characteristics of Burdur Kökez yogurt that is offered for sale at the local bazaars in Mediterrean region in Burdur provience in Turkey.

\section{MATERIALS AND METHODS}

\section{Materials}

\subsection{Milk and Yogurt samples}

The present study was conducted with milk and Kökez yogurt samples collected from Kökez Village in Burdur Province, Turkey. They were transferred to the Burdur Mehmet Akif Ersoy. 
International Journal of Agriculture and Environmental Research

ISSN: 2455-6939

Volume: 07, Issue: 03 "May-June 2021"

Table 1: Cross composition of traditional strained yogurt in Turkey

\begin{tabular}{|c|c|c|c|c|c|c|}
\hline Strained yogurt \\
\hline Dry Matter & Fat & Protein & Laktoz & Ash & Acidity & References \\
\hline 18.60 & 2.21 & 13.0 & - & 1.10 & 2.27 & {$[16]$} \\
\hline 18.83 & 5.10 & - & - & 1.61 & 2.35 & {$[17]$} \\
\hline 22.1 & 5.02 & 13.31 & - & 1.43 & 2.64 & {$[18]$} \\
\hline 21.90 & 5.80 & - & - & 0.34 & 2.58 & {$[19]$} \\
\hline 22.74 & 6.30 & 14.97 & - & 1.39 & 1.72 & {$[20]$} \\
\hline 19.41 & 2.54 & 12.01 & 4.18 & 0.67 & 2.26 & {$[21]$} \\
\hline 26.75 & 7.90 & - & 7.48 & 1.62 & 2.02 & {$[22]$} \\
\hline 21.39 & 7.59 & - & - & 1.10 & 2.74 & {$[23]$} \\
\hline 32.36 & 7.58 & 19.02 & 4.79 & 0.98 & 2.44 & {$[24]$} \\
\hline 21.90 & 5.53 & 12.55 & 3.07 & 0.79 & 1.80 & {$[9]$} \\
\hline 29.44 & 5.55 & - & - & - & 1.31 & {$[25]$} \\
\hline 24.03 & 10.82 & - & - & - & 1.90 & {$[26]$} \\
\hline 22.90 & 4.10 & - & - & 0.18 & 1.38 & {$[27]$} \\
\hline 22.23 & 8.48 & - & - & - & 1.76 & {$[28]$} \\
\hline 19.11 & 6.15 & 7.82 & 3.96 & 0.78 & 1.10 & {$[2]$} \\
\hline 23.88 & 5.36 & - & - & - & 2.09 & {$[29]$} \\
\hline Salted Yogurt & \multicolumn{7}{|l|}{} \\
\hline Dry Matter & Fat & Protein & Laktoz & Salt & Acidity & References \\
\hline 26.6 & 10 & 9.8 & - & 4.9 & 2.7 & {$[30]$} \\
\hline 25.3 & 9.0 & 10.04 & 1.43 & 4.11 & 2.03 & {$[31]$} \\
\hline 24.3 & 9.6 & 9.4 & - & 4.3 & 2.20 & {$[32]$} \\
\hline Winter Yoghurt & \multicolumn{7}{|l|}{} \\
\hline 17.16 & 6.71 & 6.48 & - & - & 2.06 & {$[33]$} \\
\hline 24.40 & 9.35 & 9.65 & - & - & 1.50 & {$[14]$} \\
\hline 25.36 & 5.65 & - & - & 4.05 & 1.27 & {$[34]$} \\
\hline
\end{tabular}

University Food Agriculture and livestock Higher Education School research laboratory under refrigerated conditions $\left(4^{\circ} \mathrm{C}\right)$ and immediately analyzed.

\subsection{Physical and chemical analyses}

The total solids, fat, total protein, $\mathrm{pH}$ and lactic acid contents of milk were determined according to the Association of Official Analytical Chemist methods [37]. $\mathrm{pH}$ was determined by a $\mathrm{pH}$ 
International Journal of Agriculture and Environmental Research

ISSN: $2455-6939$

Volume: 07, Issue: 03 "May-June 2021"

meter (Hanna Instrument pH 211; Microprocessor pH meter, Germany) equipped with an electrode (H1 1131, Germany). Protein was determined based on total nitrogen content using the Kjeldahl method and multiplying by a factor of 6.38. Fat was determined using the Gerber method. Total solids content was determined using the gravimetric method and then oven drying in a laboratory at $105^{\circ} \mathrm{C}$ for $24 \mathrm{~h} \mathrm{[37].}$

\subsection{Statistical analyses}

All of the statistical calculations were performed using SPSS v. 19 (IBM Corp., Armonk, NY, USA) and the obtained values are presented as the mean \pm SE [38] (Draper and Smith, 1998).

\section{RESULTS AND DISCUSSION}

Burdur Kökez yogurt is a local type used in Turkish cuisine, which differs from that from the milk of grazing animals in the plateaus of Kökez in the center of Burdur by its distinctive production method and an aroma different from that of strained yogurt. The most important feature of Kökez yogurt is its taste and texture. Kökez yoghurt is one of the most popular varieties of traditional concentrated yoğurt manufactured within the Mediterranean region of Turkey. The product has a cream/white color, a soft and smooth body, and is highly spreadable with little syneresis and the basic flavors are defined as sweet, sour, and astringent.

\subsection{Traditional method of yogurt production}

Milk to be used in yogurt production is pasteurized in copper boilers at $95^{\circ} \mathrm{C}$ for $20-30 \mathrm{~min}$ in a wood fire. After pasteurization, it is transferred to $20-\mathrm{kg}$ containers and left to cool for $\sim 5-6 \mathrm{~h}$. The temperature cools to $40^{\circ} \mathrm{C}$ (milking temperature) in summer and $45^{\circ} \mathrm{C}$ in winter. Two table spoons of strained yoghurt are added to the Kökez yogurt from the day before. This was then left to incubate at $40^{\circ} \mathrm{C}$ for $5 \mathrm{~h}$. The incubation period was terminated when the yogurt releases its slightly greenish water. After that, the yoghurts are taken to a storage room set at $4^{\circ} \mathrm{C}$ and stored overnight. The following day, the yoghurt is transferred onto filter cloths made of cotton, hanged on a high hanger in a room at $4^{\circ} \mathrm{C}$, and drained after overnight refrigeration. Drainage was achieved at $4^{\circ} \mathrm{C}$, and the volume of whey separated was measured periodically. After $24 \mathrm{~h}$, the cloths are removed from the hanger and stacked on top of each other to continue to drainage the yoghurt (Fig.1). This has been marketed in the public markets and restaurants within the surrounding area to more than 40 years in Burdur. 


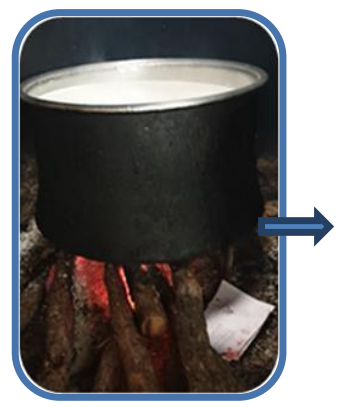

Pasteurization in wood fire $\left(90-95^{\circ} \mathrm{C} 5 \mathrm{~min}\right)$

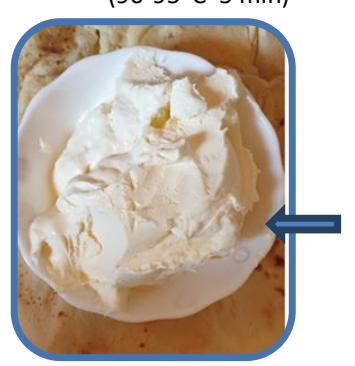

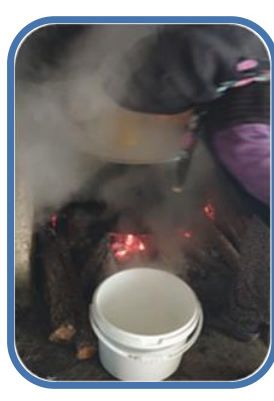

Transfer to fermenting containers

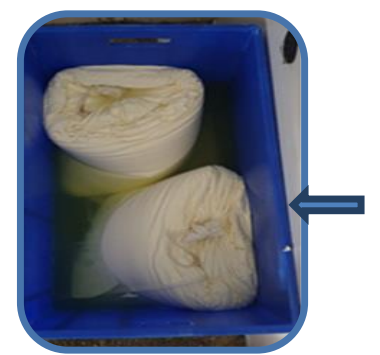

Whey of and press process in cold storage (24 h)

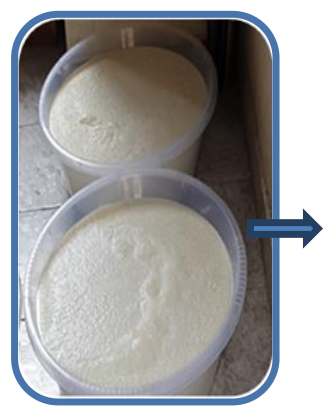

Left to cool on its own (5-6h)

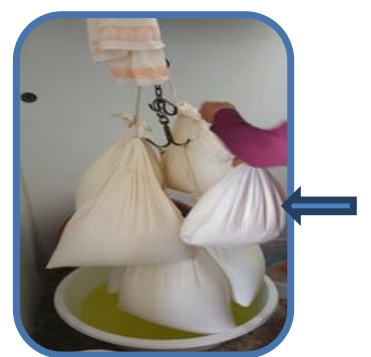

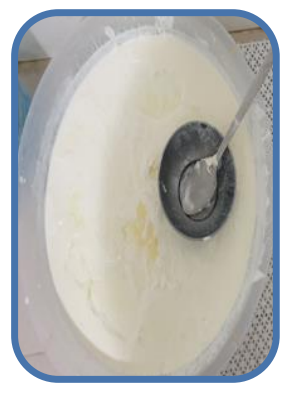

Inoculation $40^{\circ} \mathrm{C}$

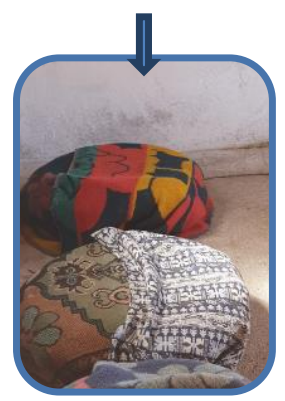

Incubation $40^{\circ} \mathrm{C} 5 \mathrm{~h}$

Figure 1: Traditional method of producing Kökez yogurt.

\subsection{Gross composition}

The $\mathrm{pH}$ values of Kökez yoghurt vary between 3.63 and 3.79, titratable acidity at $1.52-2.08 \%$ LA, dry matter at $21.25-27.35 \%$, protein content at $9.18-11.92 \%$, and fat content at $7.80-8.40 \%$. Table 2 lists the gross composition of Kökez yoghurt.

Table 2: Cross composition of Kökez yogurt.

\begin{tabular}{|c|c|}
\hline Component & Meana $^{a}$ \\
\hline Fat (\%) & $8.00 \pm 0.10$ \\
\hline Protein (\%) & $10.87 \pm 0.46$ \\
\hline Lactose & $5.57 \pm 0.02$ \\
\hline Dry matter(\%) & $23.03 \pm 1.00$ \\
\hline $\operatorname{Ash}(\%)$ & $0.72 \pm 0.02$ \\
\hline $\mathrm{pH}$ & $3.71 \pm 0.02$ \\
\hline Acidity $(\% \mathrm{LA})^{\mathrm{b}}$ & $1.87 \pm 0.08$ \\
\hline
\end{tabular}

${ }^{a}$ Mean values \pm standard deviations of 10Kökez yoghurts.

${ }^{\mathrm{b}}$ Titratable acidity expressed as g lactic acid $100 \mathrm{~g}^{-1}$ yoghurt. 
International Journal of Agriculture and Environmental Research

ISSN: 2455-6939

Volume: 07, Issue: 03 "May-June 2021"

The dry matter content of Kökez yoghurt was found to be between $21.25 \%$ and $27.25 \%$ (average 23.03\%). These values are in agreement with those reported in previous studies [26, 2, 29]. It was found to be lower than the findings of some researchers $[22,24]$ and higher than others $[2$, $17,21]$ and lower than that found in the Tulum yoghurt [8] and Winter yoghurt [31]. As the researchers stated, the difference in dry matter values is due to the composition of the milk used in production, the production technique, and the pressing method during the straining stage $[9$, 26].

The fat content ranged from 7.80 to $8.40 \%$. Similar to our findings, other researchers have reported values ranging between 5.53 to $10.82 \%$ in strained yoghurts $[9,13,18,26,39]$. Furthermore, similar fat values were also found by Uysal et al. [21] and Sömer and K1lı̧ [28]. In the Turkish Food Codex Communiqué on Fermented Dairy Products, in the section on strained yogurt, the amount of milk fat in full-fat yogurt is specified as $\geq 3.8 \%$. The average amount of fat $(8 \%)$ of the yogurt samples taken is above the value specified in the codex [40].

The average protein content of yogurts (10.87\%) was found above the values specified in the codex. It is stated in the Turkish Food Codex that the protein content of full-fat yogurts should be at least $5.6 \%$. The results of this work indicated that strained yogurts are an essential source of animal protein in the diet $[24,28]$.

According to the results obtained, the average acidity values are consistent with the studies of Kurdar and Gün [9], Tekinşen et al [26], and Şimşek et al [27] and lower than by Tatlı [18], Atamer et al. [21], Uysal et al [22], Çağlar et al. [24]. The acidity differences may result from a variety of causes: production technique, raw milk quality, higher levels of starter culture added to the milk, the acidity level of the starter culture, high incubation temperature and long incubation period, and/or ineffective cooling after incubation and during storage conditions [9, 26,28,29].

A pH range of 3.52 to 3.94 was found in the Kökez yoghurts in this study. Atamer et al. [21] stated $3.52 \mathrm{pH}$, Seçkin and Nergiz [41] $3.67 \mathrm{pH}$, in strained yogurts. According to Kurdar and Gün [42], pH 3.38-3.91, Kırdar and Gün [9] 3.69, Şahanand Kaçar [43] 3.76, Şimşek et al. [27] reported that it was between 3.65-4.22. The $\mathrm{pH}$ values obtained as a result of the research are similar to the research results stated.

The characteristics of strained yogurt are affected by the production parameters, such as the lack of a standard production technique, composition of the milk, processes applied to the milk, cultures used, acidity of the yogurt before filtering, structure of the filtering bags, filtering method, whey-off time, and press process applied. Although the production of Kökez yoghurt is similar to that of strained yoghurt, the differences in production parameters, such as 
pasteurization temperature, starter culture amount, incubation time and temperature, and wheyoff time, affect product properties.

\section{CONCLUSION}

Preserving the diversity of our traditional products and bringing them in line with current technology is of great importance for the development of yogurt technology. It is inevitable that the technologies of local dairy products, which are produced locally but remained in the closed house economy and even have been forgotten because of changing conditions, are examined and developed, and their characteristics are determined and commercial production is inevitable.

The results of the present study will help create an important inventory within the geographic parameters of the product.

\section{ACKNOWLEDGEMENT}

The present study was supported by the TUBITAK 2209-A National Undergraduate Student Research Projects Support Programme.

\section{REFERENCES}

[1] Tetra Pak Dairy Processing Handbook, (2015). Fermented milk products. [online] Available at https://dairyprocessinghandbook.tetrapak.com/chapter/fermented-milkproducts [Accessed 27 May. 2021]

[2] Keser R. A.(2018) Determination of some properties of strained yoghurt whey asan industrial waste produced from two different dairy plants, Burdur Mehmet Akif Ersoy Unive. Inst. Health Sci., Dept Animal Prod., Hyg. Technol. (Disciplinary), Burdur, MSc Thesis, Turkey. (InTurkish).

[3] Robinson, R. K. , Tamime, A. Y. ,1990 Microbiology of fermented milks, in: Robinson R.K. (Ed.) Dairy Microbiology-The Microbiology of Milk Products, 2nd ed, Elsevier Applied Science Publishers, London: pp. 291-343

[4] Tanevo-Angelova, T., Balabanova, T., Boyanova, P., Dora Beshkova., D. 2018. Traditional Balkan fermented milk products. Engineering Life science, (11): 807-819. doi: $\underline{10.1002 / \text { elsc. } 201800050}$

[5] Tamime, A.Y, Crawford R.J.M, 1984. The microbiological quality of yoghurt cheese (known in theLebanon as Labneh Anbaris) after one year storage at $20{ }^{\circ} \mathrm{C}$ Egyptian Journal of Dairy Science,12:299-312 
[6] Kurmann J.A, Rasic J.L, Kroger, M. 1992. Encyclopedia of Fermented Fresh Milk Products, Van. No stand Reinhold: New York.

[7] Yildiz, F. 2010. Development and manufacture of yogurt and other functional dairy products. Boca Raton, FL: CRC Press/Taylor \& Francis.

[8] Yaygin, H. 1999. Yogurt technology. Akdeniz University Faculty of Agriculture Food Engineering Department Press No: 75 Antalya.(In Turkish)

[9] Kırdar, S., Gün, İ. 2002. Physical, chemical and microbiological properties of strained yoghurt consumed in Burdur. Food, 27(1):59-64. (InTurkish).

[10] Tamime, A.Y, Robinson, R.K.1999.Yoghurt Science and Technology. Pergamon Pres Ltd. Woodhead Publishing. Cambridge, England

[11] Al-Kadamany, E., Khattar, M., Haddad, T. \& Toufeili, I. 2003. Estimation of shelf-life of concentrated yoghurt by monitoring selected microbiological, physicochemical changes during storage. Lebensmittel Wissenchaftund Technology, 36, 407-414

[12] Özer, B. H. 2006. Yogurt Science and Technology. Sidas Medya Ltd. Şti. İzmir, 490s. (In Turkish)

[13] Köse Ş, Ocak, E. 2011. Changes occuring in plain, straining and winter yoghurt during the storage periods. African Journal of Biotechnology. 10(9):1646- 1650.

[14] Kurdar, S., Gün, İ. 2000. A Research on Quality Criteria of Strained Yogurts Produced in Burdur. S.D.Ü. Journal of Institute of Natural and Applied Sciences, 4(1):103-110. (In Turkish).

[15] Köse, Ş. 2018. Winter yoghurt. Iğdır University Journal of Institute Science and Technology. 8(2): 115-121.

[16] Eralp, M.1953. Torba Yogurt, Nur Matbaas1, Ankara, s: 8. (InTurkish).

[17] Kayıkçılar, E.1971. Investigations on the Making and Properties of Torba Yogurt in Izmir, Graduation Thesis. Ege University, Faculty of Agriculture, Department of Dairy Technology, İzmir.p17. (InTurkish).

[18] Atay, N.1979. Studies on the Properties and Composition of Torba Yoghurts in the Aegean Region. Graduation Thesis. Ege University, Faculty of Agriculture, Department of Dairy Technology, İzmir. 
International Journal of Agriculture and Environmental Research

ISSN: 2455-6939

Volume: 07, Issue: 03 "May-June 2021"

[19] Tatll, F. 1984 Studies on the Structure and Properties of Strained (Torba) Yoghurts, Graduation Thesis. Ege University, Faculty of Agriculture, Department of Dairy Technology, İzmir. (In Turkish).

[20] Töral, A.R., Tekbıyık, L. İldes, Z. 1985. Chemical and Technological Research on Bag Yogurt in Denizli and its Region. Journal of Pendik Veterinary Institute., 17(1-2):23-24.

[21] Atamer, M., Sezgin, E., Yetişmeyen, A. 1988. Investigation of somequalities of Torba yogurts. Journal of Food, 13 (49): 283-288.

[22] Uysal, H., Kınık, Ö., Kesenkaş, H., Akbulut, N.2003. A research on theuse of Simplesse ${ }^{\circledR} 100$ in the production of low calorie concentrated yogurt. Journal of Food, 28 (2): 189-194.

[23] Uğur, A.1994.Studies on the Making and Properties of Torba Yoghurts. Graduation Thesis. Ege University, Faculty of Agriculture, Department of Dairy Technology, İzmir.

[24] Çağlar, A., Ceylan, Z.G., Kökosmanl1, G.1997. A research on the chemical and microbiological properties of toba yogurts. Journal of Food, 22 (3): 209-215. (In Turkish).

[25] Parlak, Y. 2002. The Effect of Preservative Culture Use on Some Properties of Strained (Torba) Yogurt, Ankara University, Institute of Science and Technology, Master Thesis, Ankara. (InTurkish).

[26] Tekinşen, K.K., Nizamlığlu, M., Bayar, N., Telli, N., Köseoğlu, İ.E. 2008. Some microbiological and chemical properties of strained yoghurts produced in Konya. Journal of Veterinary Sciences, 24(1):69-75.

[27] Şimşek, B., Gün, İ., Çelebi, M. 2010. Protein Profiles of Strained Yogurt Produced in Isparta Region and Their Relationship with Chemical Properties. Yüzüncü Yıl University Journal of Agricultural Sciences, 20 (3): 208-213.

[28] Sömer, V.F., Başyiğit K.G. 2012. Determination of microbiological, physicochemical properties and biogenic amine content of yoghurts 3. Traditional Foods Symposium, 1012 May, Konya, p: 480. (InTurkish).

[29] Akarca, G, Tomar, O. 2019. Chemical and Microbiological Properties of Strained Yogurt Sold in Afyonkarahisar District Markets. Akademic Food, 17(2): 212-216 
International Journal of Agriculture and Environmental Research

ISSN: 2455-6939

Volume: 07, Issue: 03 "May-June 2021"

[30] Biçer, O., Güler, M.B., Keskin, M., Kaya, Ş., 1995. Goat production some traditional goat milk products with special referance to hatay region of Turkey. Seminar on production and utilization of ewes and goat milk, Greece.

[31] Şahan N, Say D, 1998. A research on salted yoghurts produced in Hatay province. Traditional dairy products, National Productivity Center Publication No:621, V. Milk and Dairy Products Symposium, 21-22 May, Tekirdağ. (In Turkish).

[32] Guler MB, Avşar YK. 1999. Salted yogurt: a traditional taste. Food Science and Technology Congress in the 2000s, 18-20 October 1999, Izmir, pp. 70

[33] Ocak E, Akyüz N, 1998. A research on the sensory, microbiological and chemical properties of winter yoghurts produced in Van and its region. V. Milk and Dairy Products Symposium, 21-22 May, Tekirdağ. (In Turkish).

[34] Kesenkaş, H., Karagözlü, C., Yerlikaya, O., Özer, E., Akpınar, A.2017. Pysico chemical and Sensory Characteristics of Winter Yoghurt Produced from Mixtures of Cow's and Goat's Milk Journal of Agricultural Sciences 23: 53-62.

[35] Kurdar S, Gün İ(1999): A Research on Strained Yogurt Production Technology. Food Science and Technology Congress in the 2000s, 18-20 October, İzmir, p 102. (In Turkish).

[36] Güldaş M., Atamer, M.1995. The effect of pasteurization norm and storage temperature of yogurt on quality in durable yogurt production. Journal of Food, 20 (5): 313-319.

[37] AOAC (2003). Official Methods of Analysis. 17th ed. Washington, DC: Association Official Analytical Chemists.

[38] Draper, N.R., Smith, H. 1998. Applied Regression Analysis. Third Edition John Wiley and Sons, NewYork.

[39] Gökçe R, Çon AH, Gürsoy O (2000). Investigation of chemical and microbiological quality of yoghurt bags produced in Denizli in summer and winter seasons. Pamukkale University Engineering Faculty Journal of Engineering Sciences. 7(1):81-85

[40] Turkish Food Codex Communiqué on Fermented Dairy Products, Communiqué No: 2009/25, 16.02.2009/27143, Official Gazette, Ankara.

[41] Nergiz, C., Seçkin, K. 1998. The losses of nutrients during the production of strained (torba) yoghurt. Food Chemistry,61: 13-16. 
International Journal of Agriculture and Environmental Research

ISSN: 2455-6939

Volume: 07, Issue: 03 "May-June 2021"

[42] Kırdar, S., Gün, İ. 2000. A Research on Quality Criteria of Strained Yogurts Produced in Burdur. Suleyman Demirel University Journal of Institute of Natural and Applied Sciences, 4(1):103-110. (InTurkish).

[43] Şahan N, Kaçar A (2002). Nutrients transferred to serum from yogurts with different acidity during bag yogurt production. 7th Food Congress, Ankara, pp: 759-766.. (In Turkish). 